KAPITEL 8

\title{
Avslutande analys
}

I sin krönika över kommunismens 1900-talshistoria skriver den franske historikern François Furet att många europeiska intellektuella under mellankrigstiden hade svårt att välja mellan kommunism och nazism. Kartan hade ritats om efter första världskriget, kejsardömena hade fallit, men Woodrow Wilsons a mbition att göra "the world safe for democracy" visade sig mera komplicerad att sätta i verket än vad man först trott. Den liberala demokratins brist på exekutiv kraft tolkades som brist på livskraft, och många sökte sig till det radikalpolitiska fältet. ${ }^{548}$ Flera av de renegater som nämnts initialt i denna bok, inte minst den frontgeneration som Dan S. White talar om, går också att inrangera i detta mönster. Man sökte socialismen, men tvangs kontinuerligt att ompröva den socialism man tyckte sig ha funnit och istället söka efter en ny. ${ }^{549}$

Även de aktörer som här stått i centrum, Nils Flyg och Sven Olov Lindholm, kan ses i detta sammanhang. Båda sökte kontinuerligt genom sina liv efter alternativa socialistiska resurser sedan de lämnat sin ideologiska ursprungsposition bakom sig. För Flyg är situationen särskilt tydlig. Han gör genom sitt avfall till nazismen under 40 -talet väsentligen samma sak som den maoistiska vänstern senare kom att göra under 70-talet: avfärdar den sovjetiska kommunismen som en degenererad form av kommunism och tar den sovjetiska konflikten med Nazityskland, eller i det senare fallet Kina, som en intäkt för att det i själva verket är dessa stater som är den sanna socialismens framtid. För Lindholm är situationen inte lika tydlig. Visserligen sker hans avfall under den maoistiska vänsterns storhetstid, och visserligen anger han vid enstaka tillfällen Mao Zedong som inspiratör. Men samtidigt innehåller Lindholms senare ställningstagande element som delvis gör 
hållningen svår att förstå som en form av socialism. Snarare skulle man kunna säga att Flyg använder Tyskland som en alternativ antikapitalistisk resurs, medan Lindholm använder den nya vänstern under 70-talet som en alternativ antimaterialistisk resurs med klara stråk av konservatism. Svårigheterna att exakt positionsbestämma Flyg och Lindholm illustrerar väl det radikalpolitiska fältets förändring under 1900-talet där inte heller en så central skiljelinje som den mellan radikalism och konservatism är alldeles uppenbar.

\section{Flyg och Lindholm - en jämförelse}

Det har blivit dags att summera Flygs och Lindholms idéutveckling och ställa deras ideologiska biografier i ett jämförande ljus. I linje med Freedens metodologiska utgångspunkter har i båda fallen identifierats en uppsättning ideologiska kärnbegrepp: ett antal sammanlänkande teman som ömsesidigt bidrar till förståelsen av varandra. I ett första läge har ett kärnkluster för perioden före övergångarna identifierats. Även om det över tid går att se vissa rörelser också här sammanfattar dessa kluster Flygs och Lindholms ideologiska utgångspunkter före respektive "avfall". I det andra läget har förändringarna i kärnklustret efter den ideologiska övergången analyserats. Fokus har här legat dels på de begrepp som kvarstår i idémängdens kärna, och alltså visar på en ideologisk kontinuitet, dels på de delar av det ursprungliga kärnklustret som fallit bort efter övergången. I linje med den metodologiska utgångspunkten innebär dessa bortfall också att de kvarvarande kärnbegreppens betydelse, åtminstone potentiellt, förändrats.

De kärnbegrepp som identifierats i en första fas är i Flygs fall antikapitalism, antiimperialism, antimilitarism, antikominternism, idealisering av arbetet och arbetarstaten Sovjet, samt i Lindholms fall antisemitism, antikapitalism, antiimperialism, antimaterialism, idealisering av arbetaren samt arbetarstaten Tyskland. Det finns således viktiga likheter men också skillnader. I den mån likheterna är slående ska detta inte misstolkas som en bristande dynamik i studien, utan istället ses som ett forskningsresultat i sig - kontinuiteterna är på många sätt påfallande. Det gäller inte bara den rent begreppsligt ideologiska analysen, utan 
också det faktum att Flyg och Lindholm förhåller sig på ett likartat sätt till den samtida händelseutvecklingen, exempelvis krigen i Finland respektive Norge. De omfattande kontinuiteterna aktualiserar också frågan huruvida det är renegaterna eller renegaternas omgivning som rör på sig. I förhållande till begreppen ovan kan också noteras att Flyg såväl som Lindholm båda förskjuter den liberala versionen av demokrati. Någon skulle därför möjligen anse att antiliberalism eller antidemokrati vore lämpliga kärnbegrepp att närmare dissekera. Det kan dock snabbt konstateras att de båda aktörernas huvudinvändning mot den liberala demokratin ligger i systemets brist på ekonomisk maktfördelning, varför kärnbegreppet "antikapitalism" och de delar av kärnklustret som nära kan relateras till detta begrepp får anses täcka stora delar av liberalism- och demokratikritiken. Detta faktum hindrar i sig inte att den framselekterade kärnan av begrepp kan problematiseras.

\section{Likheter}

Man kan konstatera att kärnklustren såsom de identifierats överlappar varandra på tre punkter. Det gäller antikapitalism, antiimperialism samt tron på arbetarstaten som en kontrast till det förtryck kapitalism och imperialism ger upphov till. Det finns härtill en gemensam tro på att kapitalism och imperialism hänger samman. Hos Lindholm blir detta synligt i uppfattningen att det judiska sökandet efter världsherravälde är en följdverkan av den judiska kapitalismen. I Den Svenske menar man sig också ha funnit att Flyg närmat sig nationalsocialismen via uppfattningen att imperialismens kapitalistiska grundval är judisk och att den imperiala attacken primärt riktas mot Tyskland. Det är dock till synes inte Flygs egen uppfattning, som istället utgår från Lenins tankar om imperialismen som kapitalismens högsta stadium. Även om Lindholm "etnifierar" kapitalet och definitionsmässigt ser det som judiskt, finns i sammanlänkningen av kapitalism och imperialism en central likhet. Den bekräftas också av en påfallande enighet kring vilka stater, organisationer och dokument som inkarnerar denna förhatliga imperialism: Storbritannien, Nationernas förbund och fredstraktaten i Versailles.

Till likheterna inom ramen för det imperialistiska temat ska dock 
också läggas en skillnad. Lindholms antiimperialism vilar på två olika angränsande begrepp; å ena sidan ses den i linje med ovanstående som en logisk följd av antikapitalismen, å andra sidan knyts den intimt till begreppet "nation". Av tanken på den nationella okränkbarheten följer logiskt att inga imperiala, expansionistiska strävanden kan anses legitima. Det är ett argument som till synes aldrig förekommer hos Flyg. Hos Lindholm finns det däremot redan 1926, och det är också denna begreppsliga konnotation som är kvarstående då han i sin senare fas engagerar sig i FNL-rörelsen och det vietnamesiska folkets rätt till sin egen nation. Oaktat skillnaderna mellan Flyg och Lindholm är deras grundläggande enighet dock en smula pikant: Hannah Arendt identifierade just imperialism som en central faktor bakom utvecklingen i kommunismens Sovjet och nazismens Tyskland. ${ }^{550}$ Här är istället de båda kommunist- och nazistledarna överens om en grundläggande antiimperialism - bland annat då man ser sitt eget ideologiska projekt vara utsatt för just imperialistisk aggression. Det är ett märkligt förhållande som kan noteras.

Kärnbegreppet arbetarstat gestaltas på olika sätt för de båda svenskarna. Flyg ser tidigt Sovjetunionen som en sådan. Efter en lång desillusionerad period växlar han sedan över till Tyskland, understödd av ett i grunden marxistiskt tänkande om samtidshistorien som en dialektisk kamp mellan socialism och kapitalism där ett tredje alternativ inte ges. Sovjets utveckling mot imperialism (bland annat genom medlemskapet i NF) och Tysklands konflikt med denna sovjetiska imperialism tas nu som intäkt för att Tyskland måste betraktas som en i grunden socialistisk stat. Att utvecklingen obevekligt går mot socialism anses alltjämt klart. Att ställa sig på socialismens sida är alltså att ställa sig på historiens sida, historicismen är med andra ord intakt. Däremot hyllas aldrig Tyskland på samma sätt som Sovjetunionen, och omdefinitionen sker också i en för Flyg mera tryckt situation. De yttre förutsättningarna för valen av arbetarstat är med andra ord olika. Däremot kan det noteras att Tyskland och Ryssland tidigt ses som över tid jämbördiga pretendenter på att ligga i revolutionsutvecklingens framkant - ibland tar den ena täten, ibland den andra, som Flyg med stöd av Lenin uttrycker saken. Berlin är en väl så lämplig hemmahamn för världssocialismen 
som någonsin Moskva. Denna öppenhet är initialt knuten till begreppet "antiimperialism", på tanken att Tyskland såväl som Sovjet är utsatta för västmakternas imperialistiska aggression. Detta synsätt verkar småningom i protysk riktning.

Då det gäller Lindholm och arbetarstaten kan det konstateras att hans idé att Hitler gett folket socialism är just den idé som Flyg tar över under 40-talet. Hitlers vägran att underordna sig den judiska kapitalismens förmenta diktat skildras som just en kamp mellan socialism och kapitalism. I denna mening är också Lindholms tänkande präglat av en (pseudo)marxistisk dialektik. Efter kriget lämnar Lindholm idén om Tyskland som socialistisk arbetarstat bakom sig. Han gör stegvis en omprövning av Hitler, och identifierar alltmera tydligt morden på Strasserfalangen 1934 som ett brytningsår. Det var då, menar Lindholm i efterhand, som denna tyska variant av socialism spårade ur - en tankefigur som generellt är återkommande i såväl Flygs som Lindholms fall. Detta innebär dock inte att Lindholm, som en spegelbild av Flyg, med en dialektisk pendelrörelse sluter upp bakom Sovjetstaten. Han sluter inte upp bakom någon annan stat heller. I Lindholms andra ideologiska fas är nämligen arbetarstaten som begrepp och idé överspelad. Istället fokuseras behovet av internationalism, rentav en världsregering. Internationalismen betecknas nu som en nödvändighet för mänsklighetens överlevnad. I avsaknaden av ett positivt socialistiskt exempel finns således också en brygga till begreppet "antimaterialism" genom att tonvikten nu hamnat på fördelning av jordens knappa resurser. I cirkulär till gamla partikamrater, i sitt minnestal vid partimartyren Hallberg-Cuulas grav och framför allt i de senare upplagorna av Döm ingen ohörd är detta tydligt. För Flyg byter idén om arbetarstaten alltså sitt objekt, medan den för Lindholm försvinner ut mot den ideologiska periferin.

Det kan finnas skäl att här beröra relationen mellan det nationella och det internationella sammanhanget, socialismens territoriella utsträckning om man så vill. Relationen mellan kommunism och nazism brukar i denna fråga schematiskt beskrivas enligt följande: den marxistiska socialismen ser den kapitalistiska produktionsordningens exploatering som konstant och oberoende av nationsgränser. En konsekvens av detta är att proletariatets kamp för upprättelse också måste vara 
världsvid. Det är av detta skäl proletärer i alla länder ska förena sig, som Kommunistiska manifestets slutord lyder. Den klasskamp som enligt Marx i denna globala politiska strid är fundamental, ses däremot ur en nazistisk horisont istället som ett hot. Klasskampen ställer landsmän mot varandra och hotar nationen, vars kvaliteter främst ligger i dess historiska och organiska framväxt, ofta beskriven i mytiska termer. Fundamentet ligger alltså $\mathrm{i}$ att klasser korsar nationsgränser och att den politiska potential som följer av detta beskrivs som positiv eller negativ. Denna schematiska skiljelinje går att se också i materialet om Flyg och Lindholm. Icke desto mindre går det att betrakta båda som socialister: det är det sociala rättfärdighetssträvandet som står i centrum hos dem båda, det man över tid ändrar åsikt om är socialismens "arenor". Det man söker svar på är frågan: inom vilka gränser kan socialismen byggas?

Flyg har tidigt en internationell ambition att bygga en världsvid socialism på centralistisk grund, fastlagd av Komintern i Moskva. När han utesluts ur Komintern 1929 medför detta hos honom också en stark kritik av att det ryska kommunistpartiet fått ett alltför stort inflytande i organisationen. Komintern ansågs ha anträtt nationalismens väg, där enskilda nationers behov ställdes framför de gemensamma. Då Flyg ställts utanför Komintern innebar detta dock paradoxalt nog att han fick gå i samma riktning som kritiken, mot en växande nationalism. Socialismen måste formas på olika sätt beroende på förutsättningarna, hävdade han nu, och han åberopade lärofadern Lenin som stöd för denna avvikelse från den principfasta internationalismen.

Detta har i undersökningen jämförts med vad Lindholm säger om nationalismen med stöd i Hitler: den kommer att ha sina egna varianter. Nationalismen kan aldrig uttryckas i centrala diktat med mindre än att den gör våld på sitt eget fundament, nationens okränkbarhet och egenart. Det finns härtill också visst stöd för tanken att Lindholm ser nationalismen snarast som en form av socialism. Han menar redan i sin första artikel 1926 att nationen är den lämpligaste arenan att bygga social rättfärdighet utifrån. Det är denna sociala ambition som nationen ska tjäna. Nationen är således i Lindholms tanke ingen hierarkisk struktur. Tvärtom ligger hans syn på nationen i linje med vad han i Svensk frihetskamp skriver om soldatsocialismen: ett samhälle orga- 
niserat som ett regemente, vars centrala värde är att alla oberoende av social tillhörighet behandlas lika och ges samma förutsättningar från start. Då Lindholm senare rör sig mot internationalismen står den sociala rättfärdighetstanken, knuten till idén om global omfördelning, alltjämt stark.

Inom ramen för temat om internationalism kontra nationalism som arenor för socialismen ska det också kort noteras att man hos Flyg såväl som hos Lindholm kan spåra ett drag av nordism. Inte minst gäller detta under kriget i talet om Nordens neutralitet och de små staternas rätt, men i Flygs fall även tidigare. Denna nordism kan ses som en utvidgad nationalism eller internationalistiskt substitut, men den bygger hos Flyg såväl som Lindholm på idéer om kulturell och språklig samhörighet.

Nationalismen, eller snarare nationen, aktualiserar avslutningsvis också den metodologiskt inriktade frågan om det begreppsliga kärnklustret och vad som är hemmahörande där. Särskilt Lindholm använder ju begreppet "nation" mycket frekvent. Det är dock fullt möjligt att snarare se nationen som en viktig aspekt i tre av de identifierade kärnbegreppen hos honom. För det första är, i linje med ovanstående, nationen den arena inom vars gränser socialismen ska byggas. Som arena för socialismen ges nationen en antikapitalistisk halt, och svarar mot detta begrepp. För det andra ger nationens okränkbarhet en betydelsefull ingång i den antiimperialistiska hållningen. För det tredje finns det i vurmen för natur och jord - för nationen betraktad som fosterjord - en intim koppling mellan nationen och antimaterialismen. Sett på detta sätt är det befogat att ställa nationen utanför Lindholms kärnkluster - ett synsätt som viss nyare forskning åtminstone delvis sekunderat - utan att för den skull se den som obetydlig. ${ }^{551}$

\section{Skillnader}

I undersökningen har också ett antal skillnader mellan de båda aktörernas begreppsliga kärnkluster noterats. Till de avgörande hör antisemitismen. Medan den hos Lindholm är dominant under större delen av partitiden, är den i Flygs fall ganska blygsamt företrädd också under hans pronazistiska fas. Det är dock möjligt se denna skillnad som inte 
fullt så distinkt. Antisemitismen är i Lindholms fall inte ursprunglig, och då den förekommer stöds den regelmässigt av det antikapitalistiska ställningstagandet. Detta sker på ett sådant sätt att det finns skäl att betrakta kapitalismen som den egentliga måltavlan, snarare än att se de antijudiska utfallen som rasbiologiskt grundad antisemitism. Det är den judiska makten man vill åt snarare än den judiska rasen, säger Lindholm.

Just den "judiska kapitalmakten" var något som kunde uppfattas som ett problem också i delar av Flygs ursprungliga idémiljö. Stormklockan var här inget undantag. Synbarligen gjorde dock aldrig Flyg några utfall i denna riktning. Ställer man Flyg och Lindholm sida vid sida och jämför mängden antisemitiska uttalanden kommer man strax fram till att skillnaden i absoluta tal är enorm. Det går dock även i denna åtskillnad att se en likhet: såväl Flyg som Lindholm var relativt sett "lite" antisemiter i förhållande till de idémiljöer de befann sig i. Den ungdomliga vänsterrörelse som Flyg tillhörde gick som sagt inte fri från antisemitiska stereotyper och efter sitt pronazistiska avfall omgärdades han av antisemiter som Carl-Ernfrid Carlberg, Holger Möllman-Palmgren och Per Engdahl. I dessa sammanhang gick hans egen uttryckta antisemitism från obefintlig till svag. Lindholms antisemitism var under större delen av partitiden förvisso omfattande och en väl inarbetad del i det politiska budskapet. Men i den egna rörelsen var Lindholm knappast den mest framträdande antisemiten. I denna roll framträdde istället andra: den nämnde Erik Walles, som upprättade ett kartotek över Sveriges judar; Olof Öhrström, som under sin redaktörsperiod på Den Svenske förde tidningen i en alltmer utrerad antisemitisk riktning, eller Manne Bergh, som excellerade i antisemitiska karikatyrer på förstasidorna i samma tidning. Exemplen är fler. ${ }^{552}$

Då det gäller idealiseringen av arbetaren respektive arbetet är detta två begreppsliga teman som skenbart ligger varandra nära. Så är dock inte fallet. Lindholms idealisering av arbetaren bygger förvisso också på en positiv värdering av arbetet, i vilket allt värdeskapande ingår. Den som producerar värden av skilda slag (här finns en vaghet $i$ Lindholms uttryck) är definitionsmässigt arbetare - definitionsmässigt ofta också svensk, och ställs i en etnifierad klasskamp mot det internationella judiska 
kapital som stjäl arbetets frukter. Samtidigt finns det hos Lindholm ett tydligt fokus på arbetaren som gestalt, den "kommande tidens genius", en figur med nästintill mytologiska kvaliteter.

Hos Flyg är arbetaren däremot påfallande anonym. Liksom hos Lindholm anses han ha rätt till frukterna av sitt arbete. Här delar Flyg marxismens moraliska ingångsvärde: att exploateringen av arbetarna innebär en stöld av det mervärde som adderas till en vara då den förfinas i produktionen. Men för Flyg är skapandet av mervärde viktigt i sig själv. Schematiskt kan det uttryckas så, att Lindholm idealiserar den som producerar medan Flyg idealiserar produktionen. Där Flyg ser 30-talets sovjetiska produktionsökning i relation till krisen i det kapitalistiska väst ser Lindholmpressen istället hur stachanovitsystemet vid samma tid reducerar arbetaren till en produktionsfaktor. Denna kritik av produktionens rovdrift på människorna kan spåras redan $\mathrm{i}$ Lindholms kamplyrik, och även i den mångfaldigt återgivna texten om arbetaren som "den kommande tidens gestalt" talas om att denne ska befrias från den boja som det produktiva arbetet innebär. Att arbetet är något man, i Marx efterföljd, ska göras fri från är synbarligen inte en tanke som finns hos Flyg. Den finns däremot hos Lindholm. För Flyg är det den ofrivilliga friheten från arbete - arbetslösheten - som är det större problemet.

Denna skiljelinje mellan idealiseringen av arbetet och av arbetaren är således nära anknuten till begreppet antimaterialism och till synen på materiella värden. Lindholm står på denna punkt för en över tid kontinuerlig kritik av "bukfyllnadslärornas" fokus på materiell vinning. Denna kritik tar skepnad i partitidens vurm för en ny livsstil och skapandet av en ny autentisk människa som lever närmare jorden, men också i kritiken av senare tiders urbana och njutningslystna "lättingar" som inte kan eller vill prata om något annat än mat och bilar. Just bilen är signifikant - där Flyg älskade att köra runt med sin amerikanska Dodge på vägarna runt Nacka, förkunnar däremot Lindholm att han är en svuren fiende till bilismen. Det fanns i den tyska nazismen ett starkt idealistiskt idéinnehåll, men det finns ingenting hos Flyg som antyder att denna idealism var viktig i övergångsprocessen. Han står fast vid sina materialistiska utgångspunkter. På samma sätt står Lindholm fast 
i sin antimaterialism som över åren får en allt starkare ställning i det ideologiska kärnklustret. Det faktum att Lindholm med relativ enkelhet kunde engagera sig i den nya brett definierade vänsterns frågor på 70-talet har delvis att göra med att denna vänster hade en annan inställning till materiell produktion än 30 -talets vänster.

Ytterligare en skillnad som kan noteras vid en jämförelse är antimilitarismens ställning. Den finns endast i Flygs kärnkluster. Det kan kanske synas märkligt eftersom begreppen "antikapitalism" och "antiimperialism", liksom föreställningen om deras inbördes samhörighet, finns belagda hos både Flyg och Lindholm. I Flygs värld är antimilitarismen den logiska konsekvensen av dessa antipatier. Antimilitarismen var ursprungligare än mycket annat i det ideologiska kärnklustret, och den dröjde sig kvar också sedan mycket annat börjat förändras. Småningom försvann den, åtminstone dess nära koppling till begreppet "antikapitalism". Det är dock märkbart att flera av antimilitarismens angränsande begrepp, som fred, neutralitet och en vilja att tillförsäkra Nordens länder frihet, finns kvar hos Flyg och i det senare skedet länkas till tron på Tyskland som en ny arbetarstat - det är i samarbetet med denna stat som Nordens fred och frihet ska vinnas i socialismens samverkande Europa.

Lindholm, som själv var militär, gick däremot in i politiken som en direkt konsekvens av den svenska nedrustningen på 20-talet. Det är således snarast bristen på militarism och försvarsvilja i Sverige som lyser igenom som motiverande faktorer i hans tidiga politiska engagemang. På sin ålders höst började han dock vackla i sin försvarsvilja, och engagerade sig istället i fredsrörelsen. Även han blev alltså i slutändan antimilitarist. Det är dock notabelt att Lindholm når antimilitarismen från annat håll än Flyg. För Flyg är den intimt knuten till begreppet "antikapitalism", för Lindholm i den senare fasen lika intimt till begreppet "antimaterialism". Det främsta vittnesbördet om att den moderna utvecklingen går åt fel håll är att mänskligheten lyckats skapa ett vapen som kan utplåna dess egen existens. Det är atombomben, betraktad som en frukt av den moderna materialismen, som för Lindholm fäller avgörandet. 


\section{Angränsande teman}

Vid sidan av dessa direkta jämförelser av Flygs och Lindholms ideologiska kärnkluster kan ett antal angränsande teman identifieras. En sådan central likhet är synen på den hotande kulturfaran. Den yttrar sig hos Flyg som polemik mot kortspel, "dundersupning" och Nick Carter-litteratur och hos Lindholm som en mer allmän uppmaning att bearbeta den egna karaktären. Det går att se en skiljelinje mellan Flyg och Lindholm på denna punkt i det att Lindholms polemik mot kulturfaran har en tydlig antimaterialistisk udd som Flyg saknar. Men det finns också viktiga likheter i synen på den hotande kulturfaran. För det första innebär svaret på detta hot att en ny människa måste skapas för att ett nytt och bättre samhälle ska bli möjligt. Av detta intresse för en ny och bättre människa följer också ett naturligt fokus på barn och ungdom. Ett av de tydligaste uttrycken för denna ambition är den socialistiska barngillesverksamheten i Flygs parti, men flera exempel kan ges.

För det andra kan man i synen på kulturfaran och den nya människan som ett svar på denna fara se en gemensam urspårnings- eller degenerationstematik. Påfallande ofta knyts denna idé i sin tur till tanken om en sann kontra en sviken socialism. Det är nämligen Flygs såväl som Lindholms uppfattning att socialdemokratin har ett särskilt ansvar för samtidens förfall. Att Flyg ser processen runt Andra internationalens bortdöende och partisplittringen 1917 som viktiga indikationer på den maktbärande socialdemokratins degeneration är inte underligt. Det kan dock noteras att även Lindholm har positiva saker att säga om den ursprungliga socialdemokratin och den rättskänsla som rådde under August Palms dagar. Det brott som socialdemokratin anses ha begått tolkas på liknande sätt av såväl Flyg som Lindholm: den har accepterat kapitalismen och det borgerliga samhället.

Av denna gemensamma urspårnings- och degenerationstematik följer alltså logiskt en tanke om ideologisk renhet. Men det är också viktigt att samma tematik röjer en uppfattning om historiens inneboende rörelse och gång. Till denna tanke hör också en utrerad maktanalys, som schematiskt kan beskrivas enligt följande. För Flyg såväl som för Lindholm är problemet i samtiden att en grupp människor på orätta 
grunder har makt, medan en annan grupp människor på orätta grunder saknar makt. Den politiska uppgiften består i att korrigera denna obalans, med rättvisa och social harmoni som följd. Frågan är här hur denna förändring till det bättre kan ske, och i Flygs såväl som Lindholms fall är svaret: en ny människa. Att Lindholms nya människa blickar bakåt mot ett tillstånd av ursprunglighet och strävar efter att utplåna sina materiella böjelser - drag som knappast finns hos Flygs nya människa - rubbar inte tankefigurens övergripande likhet. Sammantaget kan man således konstatera att alla idéer om kulturfaran i den degenererade samtiden, det socialistiska sveket och renheten, liksom föreställningarna om historiens gång och behovet av en ny och bättre människa, hänger samman i en helhet, och att Flyg såväl som Lindholm delar dessa uppfattningar.

Det finns också likheter i gränslandet mellan ideologi och sakpolitik att notera. Inte minst är det lätt att se hur man i inställningen till Sovjetunionen respektive Tyskland som arbetarstater är något kluven. $\AA ̊$ ena sidan behövs respektive stat som en positiv resurs i den egna politiska propagandan. Det är genom sin socialistiska förebildlighet de förvärvar sin plats i det idébegreppsliga kärnklustret. Å andra sidan finns ett starkt behov av att markera distans. I Flygs fall sker det successivt under 30 -talet, då en allt tydligare distinktion mellan samtidens Sovjetunion och de ursprungliga - "rena" för att återknyta till tidigare resonemang - revolutionära idealen växer fram. För Lindholm sker samma sak genom upprepade markeringar mot "tyskeriet" i de partisammanslutningar han över åren tillhör.

Det kan konstateras att dessa ibland något dubbeltydiga avståndsmarkeringar också praktiskt kom att manifesteras genom nya partibildningar med lösare bindning till de båda arbetarstaterna. I Flygs fall genom att han utesluts ur Komintern, i Lindholms fall genom att han efter det misslyckade kuppförsöket utesluts ur Furugårds parti.

En annan likhet som följer av dessa, om än villkorade, band till andra stater i närområdet är att såväl Flyg som Lindholm med världskrigets utbrott exponerades för anklagelser om femtekolonnverksamhet. Särskilt för Lindholm är denna anklagelse en black om foten. Det är denna förmodade opålitlighet som gör att han aldrig får åka som frivillig till 
finska vinterkriget, och samma misstankar som får honom att på eget initiativ betyga sin trohet inför Gustaf V. Femtekolonnanklagelsen var något Lindholm slogs mot både före, under och efter kriget.

För Flyg var däremot anklagelsen om rysk infiltration i Sverige länge en tillgång. Det var en anklagelse som kunde användas partitaktiskt mot de "ryska sorkarna" i den svenska Kominternsektionen. Kopplingen till främmande makt var här dessutom öppen och ideologiskt motiverad, och därmed lätt att slå mynt av. Det är betecknande att också erfarenheten av Quislings maktövertagande i Norge 1940 vänds mot de "potentiella quislingarna" i Sveriges kommunistiska parti. I Flygs senare protyska fas slår anklagelsen om tyskeri också mot honom. I vad mån denna anklagelse hade reell grund ska lämnas osagt, men det kan än en gång konstateras att Flyg i alla fall hade en etablerad kontaktyta med Nazityskland genom de återkommande bidragen till Folkets Dagblad.

En tongivande skillnad mellan Flyg och Lindholm vid sidan av det ideologiska kärnklustret är förhållningssättet till den politiska estetiken. För Lindholm är denna en starkt motiverande kraft genom hela hans politiska engagemang. Redan i skildringarna från partikongressen i Nürnberg 1929 kan man se hur positivt de nazistiska ritualerna och uppmarschkulturen uppfattas. Fanorna, talkörerna, de uniformt klädda och tågande massorna ger en demonstration av kraft som avsätter ett så djupt intryck att det finns kvar genom hela livet. I själva verket är det samma estetik som Lindholm tycker sig se i såväl FNL-rörelsen som i Folkkampanjen mot kärnkraft. Som fanbärare för FNL-grupperna ser han likheter med det egna partiets uppmarscher, och att FNL-fanans färgsättning överensstämmer med den egna rörelsens finner han djupt symboliskt. Då kärnkraftsstridens folkmassor väller in på Stockholms stadion för en gemensam slutmanifestation strax före folkomröstningen 1980 skildras stämningen på ett sätt som ligger helt i linje med Nürnberg 1929. Även här var det solfanor, talkörer och en obeskrivlig kampstämning som satte sinnet i brand. Att Lindholm i dessa rörelser tycker sig se en bredd som motsvarar hans idé om en sann klassöverskridande folkgemenskap gör inte intrycket sämre.

Då Nils Flyg och hans intryck av politikens estetiska manifestationer ställs bredvid Lindholms är kontrasten slående. Det finns ingenting som 
antyder att Flyg skulle ha lockats till vare sig den ena eller andra politiska riktningen av estetiska skäl. Enstaka markeringar om hur Nevskij Prospekt badar i ljus och människomassor väller fram i leende tåg är just inget mer än enstaka markeringar. Inte heller avfallet i protysk riktning sker med dessa förtecken. Det är ett avfall som präglas av politisk logik och beräkning, inte av ritualernas känslomässiga suggestionskraft.

Sammanfattningsvis kan sägas att en jämförelse mellan Flygs och Lindholms symmetriska övergångar rymmer likheter såväl som skillnader. Det är dessutom i flera fall så att en skenbar likhet rymmer skillnader, medan det som synbarligen är en skillnad också rymmer ett element av likhet. Det som är mest slående då det gäller Flyg, och som bidrar till att förklara den vidare ideologiska utvecklingen, är hans tidiga lanserande av Tyskland som potentiell bas för den globala socialismen. Denna protyska böjelse går i själva verket att se redan under de tidiga Kominternåren. Det kan ånyo påpekas att det positiva intresset för Tyskland som motor för den revolutionära omdaningen var brett omfattat i arbetarrörelsen, men för Flyg kom det att bli ett grundläggande rekvisit som tillsammans med kärnklustrets utveckling i övrigt fick påtagliga konsekvenser.

När det gäller Lindholm är det tveklöst mest slående de många och tidiga marxistiska tankefigurerna. Att marxismen avfärdas som en internationalistisk och splittrande lära är självklart, det är på dessa grunder nationalsocialismen allmänt definieras som en antimarxistisk ideologi. Vid närmare påseende företräder dock även Lindholm en etnifierad klasskampstanke, en idé om att imperialismen är kapitalismens följdverkan, en uppfattning att arbetaren har rätt till de värden som hans arbete skapar liksom en tanke om att arbetaren slutgiltigt ska frigöras från den boja det produktiva arbetet innebär. Det vill säga i flera led tankefigurer som kan beskrivas som marxistiska, om än inte fullt teoretiskt underbyggda. Potentiellt hade dessa idéfragment kunnat slå en bro till Lindholms senare ideologiska hemvist. Det faktum att så inte sker blir således ytterligare en illustration av det faktum att 60- och 70-talets nya vänster inte företrädde en socialism av samma slag som partierna på 3o-talet, oberoende av om den då artikulerades av Socialistiska partiet eller av Sveriges kommunistiska parti. 


\section{Flyg och Lindholm jämfört med andra renegater}

De svenska renegaternas avfall framstår som tämligen unika genom aktörernas framskjutna positioner, genom den synbarliga symmetrin och genom det faktum att avfallen sker från två håll parallellt. Däremot är de som sagt inte unika fall av renegadism under den europeiska mellankrigstiden. Flera av de renegater som nämndes som jämförbara i inledningen av denna bok tonar också fram i det material som här studerats. Redan i Holger Carlssons bok om nazismen i Sverige från 1942 konstateras med avsky att Flyg aspirerar på att bli en "svensk Doriot", något som inte tycks vara alldeles långt från sanningen. ${ }^{553}$ Flyg träffade Doriot på plats i Frankrike, och även i Lindholmrörelsens press skildras Doriot som ett föredöme. ${ }^{554}$ Likaså gratulerar Lindholm Oswald Mosley till valframgångarna, och i fallet med de norska marxister Øystein Sørensen studerat finns nära personliga band till Flyg. ${ }^{555}$ Det finns således ett antal kontaktytor att studera. Möjligen går det också att se drag av interdependens, ett ömsesidigt betingat avfall. Inte minst gäller detta Flyg och Håkon Meyer, vars kontakt och likartade ställningstagande antyder påverkan.

Som i alla komparationer finns både likheter och skillnader. Ställda bredvid flera av de europeiska renegater som nämnts i forskningsöversikten sticker Flyg och Lindholm båda ut på ett mycket iögonfallande sätt: de blev som svenskar aldrig utsatta för ockupation under kriget. Marcel Déat, Jacques Doriot, Henri de Man, Bolesław Piasecki, Eugène Olausen och Håkon Meyer framlevde alla sina liv i stater som ockuperades av tyska trupper - i fallet Piasecki senare också av sovjetiska. Dessa aktörers avfall äger i samtliga fall, åtminstone delvis, rum under eller i nära anslutning till ockupationen. Det starka yttre tryck som Ashley Lavelle identifierar som tänkbar bakomliggande faktor i en renegatprocess går alltså att se hos alla ovan nämnda. Sådana yttre faktorer kan i Flygs och Lindholms fall uteslutas. Det faktum att de som svenskar aldrig tvangs att bekänna färg vid en ockupation särskiljer dem också. Den anklagelse om potentiell kollaboration som ofta riktades mot dem får vi aldrig veta något om bärkraften $i$.

Jämte detta svenska predikament utanför den europeiska storkonflikten finns ytterligare ett par särdrag i de svenska fallen värda att notera. 
Det gäller särdrag som snarast illustrerar vad som kan kallas svensk politisk kultur. I materialet om Flyg och Lindholm kan på flera ställen urskiljas drag som stämmer överens med en intuitiv förståelse av vad som kännetecknar denna. Då Birger Furugård utesluter Lindholm ur det egna partiet 1933, inte för att han förbrutit sig mot rörelsens Führerprincip utan för att han brutit mot partiets stadga, är det ett sådant exempel. Då Kominternordföranden Dimitrij Manuilskij i sina tirader mot Flyg och Kilbom 1929 ändå ger det svenska kommunistpartiet beröm för hur väl man fullgör rapporteringsskyldigheten mot Komintern är det ett annat. I båda fallen tonar formalismen fram som ett svenskt kännetecken. I Sverige fyller man i sina blanketter och följer reglerna. Om man jämför med andra europeiska renegater är det dock två andra särdrag i gränslandet mellan ideologi och politisk kultur som sticker ut som specifika.

\section{Småstatsperspektiv och rysskräck}

För det första kan det noteras att Flyg såväl som Lindholm tydligt lyfter fram de små staternas rätt. Ofta är det just så det antiimperialistiska argumentet formuleras. Att Sverige är en liten stat i Europas utkant vars frihet och neutralitet hotas av stormakternas anlopp är uppenbart. I den meningen speglar tanken både en upplevd risk och ett egenintresse. Det är också ett intresse som Sverige anses dela med sina nordiska grannar. De nordistiska parollerna ska alltså ses i detta ljus. Temat om de små staternas rätt är i litteraturen om de renegater som nämnts ovan inget som är framträdande, inte heller hos de norska renegater Øystein Sørensen analyserar. Inte heller finns det hos Henri de Man, trots att hans hemland Belgien kan ses som just en småstat. Möjligen är de belgiska nationalitetsproblemen en faktor bakom detta, men det förblir en spekulation. Sannolikt spelar också det belgiska koloniala arvet in. I linje med detta finns småstatsargumentet inte heller hos Oswald Mosley, som istället framstår som en klassisk brittisk imperiebärare.

Det andra som kan noteras som en särskiljande faktor är antikominternismen. Det gäller då huvudsakligen Flyg. I hans fall är det den över åren allt djupare misstron mot Komintern och sedermera Sovjet 
som på många sätt avgör den politiska färdriktningen. Detta manifesterades inte minst i Silvernålskampanjen. Denna kampanj drog till sig en stor del av det antibolsjevikiska etablissemanget i Sverige, och Flyg kunde här återknyta till de antiryska stämningar som fanns företrädda i såväl Ålandsfrågan som under finska vinterkriget. I alla dessa frågor tangerade Flyg ett viktigt stråk i det svenska kollektiva medvetandet: rysskräcken. Konflikterna med grannen i öst hade över seklerna format en bergfast idé om den hotfulle ryssen; från 1300-talets gränskonflikter med Novgorod via stora nordiska kriget under 1700-talet till skärsliparnas misstänkta spionage under tidigt 1900-tal. ${ }^{556}$ I pamfletten Ett varningsord från 1912 hade Sven Hedin lagt ut texten om hur invaderande ryska kosacker skulle ta Kungsträdgården i Stockholm i besittning efter en imaginär ockupation. De ryska hästarna fick i Hedins text äta sitt hö vid fötterna av Karl XII:s staty, en bild med stark symbolisk betydelse. ${ }^{57}$ Att just Sven Hedin var en av dem som med glädje bar Flygs antikommunistiska silvernål är inte att förundras över. Tsardömet hade visat sig vara ett säkerhetspolitiskt hot mot Sverige, och det fanns inga skäl att anta att inte också Sovjetunionen var det. Den våldsamma antikominternismen faller i detta avseende väl in i en djupt liggande idémässig trend i Sverige.

Jämfört med de andra renegaterna innebär detta en avvikelse. Den enda som utvecklar en motsvarande animositet mot Komintern är Jacques Doriot. I hans fall är dock sannolikt andra faktorer överordnade. Doriot hade redan under tidigt 2o-tal haft en stark position i Komintern, och satt till och med i dess exekutiva kommitté. Enligt vissa bedömare var han på väg uppåt i organisationen då han som populär borgmästare i Saint-Denis utvecklade en folkfrontsliknande idé innan denna blev Kominterns officiella linje. Det slog tidsmässigt inte på mer än ett par månader innan Komintern svängde, men liksom i fallet Flyg uteslöts Doriot ur organisationen för bristande hörsamhet mot centralismens princip. Han förstörde med detta en god karriärmöjlighet. Istället grundade han 1936 sitt parti Parti Populaire Français, som under kriget blev ett framstående pronazistiskt kollaboratörsparti. Tar man denna förhistoria i beaktande får man i hans fall söka motviljan i personligt agg snarare än i en redan djupt känd oro för en rysk aggression. 


\section{Generationsperspektiv och antikapitalism}

I jämförelsen mellan de europeiska renegatfallen och de svenska är dock likheterna större än skillnaderna. I linje med vad Lavelle skriver kan man exempelvis fastslå att alla i sina övergångar går "med sin tid". I den socialistiska frontgeneration som White talar om gäller det samtliga, och till denna rad kan också Flyg liksom de norska marxisterna läggas. Lindholm avviker från mönstret, dels genom att hans avfall kommer senare under 6o-talet, dels för att han avfaller i motsatt riktning. Icke desto mindre är också Lindholm en exponent för tendensen att ideologiska övergångar av detta slag sker "med" tidens riktning snarare än "mot", för att tala med Lavelle. Den enda person i den tidigare uppräkningen som avviker från detta mönster är tysken Horst Mahler. Efter att ha grundat tyska Röda armé-fraktionen, och under 70 -talet suttit i fängelse för terroristbrott, släpptes han under tidigt 8o-tal. Efter en successiv positionsförflyttning under 80- och 90-tal, då han bland annat publicerade sig i tysk nationalistisk press, engagerade han sig under tidigt 2000-tal i Nationaldemokratische Partei Deutschlands. Han har vid flera tillfällen dömts för förintelseförnekelse och hatbrott, något han utan framgång försökt undkomma genom att söka politisk asyl i Ungern. Märkbart lite har skrivits om Mahlers politiska övergång. I de försök som gjorts har man bland annat pekat på antisionism som ett ideologiskt förbindelseled mellan hans båda ideologiska faser. Oaktat hur Mahlers övergång ska värderas kan det konstateras att han knappast går i tidsandans riktning då han under 2000-talet blir nazist.

Till likheterna hör också, som sagt, det faktum att många av de nämnda renegaterna tillhörde samma generation, något som också lyfts fram av Dan S. White. Henri de Man föddes 1885, Marcel Déat 1894, Oswald Mosley 1896 och Jacques Doriot 1898. I denna rad kan också Nils Flyg, född 1891, med enkelhet inrangeras. Sven Olov Lindholm, född 1903, kan med någon rätt också ses i samma sammanhang. Han gjorde, som vi kunnat se, en i flera avseenden påfallande marxistisk tolkning av nationalsocialismens idégods. Samtidigt är han något för ung för att det ska vara relevant att tala om första världskriget som en central generationsspecifik erfarenhet. Inte heller de upplevelser av svek, prövning och omprövning under Andra internationalens slutfas 
under det tidiga 10-talet som för Flyg och flera av de övriga kom att vara viktiga spelade någon roll för Lindholm. Liksom för polacken Piasecki, född 1915 i ett Polen som vid denna tid var delat och inte existerade som självständig stat, var det snarare revolutionsutvecklingen i Ryssland och senare Sovjetunionen som dominerade tankarna. Det var det hot som kom från öst som var centralt för Lindholms försvarsvilja, och det var från detta håll som hoten kom också mot Polen. Så till vida är det möjligt att se att händelseutvecklingen under första världskriget var central också för Lindholm och Piasecki. För Whites frontgeneration låg fokus oftast i väst, medan det för Lindholm och Piasecki var hotet från Sovjetunionen som stod i fokus för engagemanget.

Till de tongivande likheterna hör också flera ideologiska aspekter. I samtliga fall kan man se ett sökande efter en mera ursprunglig, "ren", icke urspårad eller praktiskt mera välfungerande typ av socialism. Denna fråga var i samtiden mera öppen än man tror. Inte minst White gör en stor poäng av att eftervärldens sökande efter en socialism som inkarnerade det objektivt sanna arbetarintresset är fåfäng möda. ”It is doubtful if there was a correct course for European socialism in the era between the wars", förkunnar han, och bidrar således liksom William Brustein och Götz Aly till att förklara de nazistiska arbetarrösterna. Det finns enligt White åtminstone fyra delar i frontgenerationens ideologiska omprövning. De är samtliga applicerbara på Flyg, men i väsentliga delar också på Lindholm trots att han förflyttade sig i motsatt riktning.

Den första och mest allmänna faktorn är det antikapitalistiska ställningstagandet. Det är en fogyta som löper mellan alla renegaternas faser och är en självklar utgångspunkt: det man söker är en alternativ socialism, inte ett alternativ till socialismen. Som vi sett gäller motståndet mot kapitalismen också de båda svenskarna. För många i frontgenerationen ansågs uppslutningen kring antikapitalismen, inte bara den marxistiska socialismens, som något i grunden positivt. En bred antikapitalism var en möjlighet, inte ett hot. En sådan, mera tillåtande, antikapitalism öppnade dörrarna mot andra delar av det radikalpolitiska fältet. ${ }^{558}$

För det andra följde med denna mera öppna antikapitalism också ett uppluckrat klassbegrepp. Att endast appellera till arbetarklassen räckte inte. För att kunna nå verklig politisk förändring behövde man ha ett 
bredare anslag. Det uppluckrade klassbegreppet vilade i denna mening på en realpolitisk analys. ${ }^{559}$ Att Lindholm företer ett bredare klassbegrepp där det inte finns några principiella hinder att äga produktionsmedel är inte förvånande. Det var just i denna ideologiska färdriktning frontgenerationen kom att gå. Men även Flyg börjar, som vi sett, under 30-talet att reflektera över begreppet "folk". I ambitionerna att göra 1 maj till en nationalsocialistisk dag och 6 juni till en socialistisk kan man se hur såväl Flyg som Lindholm försökte göra sitt eget väljarunderlag så brett som möjligt.

För det tredje vilade omprövningen på en djupt liggande historicism. Det fanns en tydlig idé, inte minst hos Henri de Man, om att de tyska nazistiska framgångarna var sprungna ur historiens inre dynamik. Även hos vissa av de norrmän Sørensen studerar går mönstret att se. En av dem, Albin Eines, menade explicit att nationalsocialismen hade historien på sin sida. Historiens lagbundenhet verkade mot kapitalismen och för nazismen. ${ }^{560}$ I denna tanke, som delades också av Flyg i hans senare fas, ges historien själv ett slags aktörsstatus. Historien väljer sina verktyg - ibland Ryssland, ibland Tyskland. Men dess inneboende målsättning att krossa den kapitalistiska ojämlikheten och bygga nästa historiska steg - socialismen - är densamma.

För det fjärde innebar det ovanstående att frontgenerationen slöt sig till tanken att Tyskland var en garant för socialismen inom ett "samverkande Europas" ram. Det är också detta nyckelbegrepp man sluter upp kring. De Man hävdade att detta tyska sociala ansvarstagande låg i den "europeiska evolutionens inre logik". Déat hävdade att Tyskland med nödvändighet skulle genomföra en social revolution i Europa, oaktat vad befolkningen tyckte. Det var helt enkelt förutskickat. ${ }^{51}$ Även Håkon Meyer slöt upp bakom en sådan analys. ${ }^{562}$

En praktisk konsekvens av denna gemensamma ideologiska utveckling är att den i många fall tvingade fram nya partier. Inte minst Oswald Mosley används av White för att illustrera detta faktum. Det gäller både hans New Party, grundat efter missnöje med att hans förslag till central ekonomisk planering avslagits, och det senare British Union of Fascists. Flygs och Lindholms respektive partibildningar kan också ses i sammanhanget. Flyg uteslöts förvisso ur Komintern, medan Lindholm 
aktivt försökte störta Furugård i en kupp. I båda fallen, liksom i fallet Mosley, används dock de nya partibildningarna för att lösa en pågående tvist inom respektive parti. Dessa uppkommande behov av en politisk nystart passar också väl in i bilden av en ideologisk förändringsprocess.

\section{Kontaktytor och eftermäle}

Det är inte lätt att helt klarlägga i vilken mån de europeiska renegaterna och de svenska träffades och potentiellt bidrog till varandras utveckling. Ömsesidig påverkan mellan Flyg och Lindholm fanns det till synes knappast någon - enligt vissa källor möttes de hos Osramdirektören Schéle sommaren 1942 för att diskutera eventuellt gemensamma initiativ, men det konkreta resultatet tycks ha varit litet. Senare tankar på valsamverkan mellan Flygs och Lindholms partier förekom också inför valet 1944. Det blev dock aldrig något av detta. ${ }^{563}$

En kontaktyta mellan de svenska renegaterna och övriga som nämnts går dock att följa över åren. Det gäller relationen mellan Nils Flyg och Håkon Meyer. De hade mötts redan på det norska socialdemokratiska ungdomsförbundets konferens 1923, och hade över åren en god kontakt ända fram till Flygs död $1943 .{ }^{564}$ Flera brev från Meyer finns bevarade i Flygs personsamling, och Meyer skickade bland annat sin skrift Historieopfatning og marxisme till Flyg med dedikation och tack för en trevlig nyårskväll $1934-35 .{ }^{565}$ Vad Flyg och Meyer talade om under det gemensamma nyårsfirandet kan vi inte veta. Men klart är att fundamenten i den marxistiska historieuppfattning Meyer lade ut texten kring i sin skrift - historicismen och dialektiken - skulle bli viktiga komponenter i hans egen övergång. Det var de som vi sett också för Flyg. I Øystein Sørensens genomgång av Meyers positionsförflyttning känns mycket igen från Flyg. Meyer menade att det pågående kriget skulle betraktas ur "dialektisk synvinkel", där den som tillskansade sig makten att krossa det gamla systemet också hade rätten på sin sida. Det var den obevekliga historien som tilldelade denna makt. Meyer laborerade i sitt historiska perspektiv med en succession av tidsepoker, där en socialdemokratisk och liberal tidsepok efterträtts av nationalsocialismens tidsepok. Det var i denna tidsepok naturligt att det nya Tyskland fick en dominerande 
roll i Europa, rentav genom skapandet av ett intereuropeiskt nationalsocialistiskt parti på tysk grund.

På andra sidan var fienderna konstanta. Det var det statskapitalistiska Sovjet och den västliga imperialismen, nu i allians med varandra. Dessa makter - Sovjet, Storbritannien och Amerika - definieras explicit som utomeuropeiska makter. Särskilt viktigt var det för Meyer att det plutokratiska England led nederlag, det skulle tjäna arbetarna väl. ${ }^{566}$

I detta resonemang känns Flyg igen. Det var, som Sørensen skriver, en nationalsocialism där socialismen var det centrala. I Meyers förståelse av nazismen som en alternativ socialism och inte primärt en raslära finns också fog för tanken att antisemitismen inte var avgörande för hans förflyttning. Detta har tidigare slagits fast i fallet Flyg. I själva verket var Meyer en än svalare antisemit än Flyg, snarast en motståndare till denna del av det nazistiska budskapet. Då de norska judarna skulle deporteras ställde Meyer vid upprepade tillfällen upp med transporter för att de skulle undgå deportation, han ställde sin lägenhet till förfogande, och han gav ekonomiskt stöd till dem. I det så kallade "rettsoppgjøret" efter krigsslutet framhölls dessa faktorer som förmildrande. Meyer dömdes till tio års straffarbete, men släpptes i förtid. Han flyttade senare till Sverige, där han startade en importfirma. Han dog i Malmö 1989. ${ }^{567}$

Avslutningsvis ska också något sägas om renegaternas eftermäle. Denna bild är sammantaget splittrad. Som konstaterades initialt i denna bok har den svenska arbetarrörelsen inte alltid varit bekväm med att hantera Flyg. Sørensen skriver på samma tema att de fem norska överlöparna ofta bemötts med tystnad och att de är arbetarrörelsens "dåliga samvete" ${ }^{568}$ Det är lätt att intuitivt förstå detta. Renegaterna gjorde ju gemensam sak med fienden, härtill en fiende som förlorade kriget och vars mest bestående politiska insats är folkmordet på Europas judar. Flyg fick själv aldrig någon chans att i efterhand förklara eller urskulda sin övergång. Lindholm däremot kämpade hela sitt återstående liv med att inskärpa sitt och den egna rörelsens oberoende av Tyskland, och tillbakavisade med kraft uppfattningen att han skulle ha blivit en svensk Quisling vid en ockupation. Att eftermälet både då det gäller Flyg och Lindholm är ganska mörkt är knappast överraskande.

Mer överraskande är att detta inte gäller alla de behandlade rene- 
gaterna. Oswald Mosley mötte över åren en större acceptans från dem som aldrig trott att den partipolitiskt ombytlige Mosley varit fascist på djupet. Hans memoarer från 1968 fick ett gott mottagande, liksom en senare biografi av Robert Skidelsky. Han gjorde flera tv-intervjuer som ofta togs väl emot. Henri de Man genomgick en liknande process. Också i hans fall publicerades en biografi, av Peter Dodge 1966. Vid tjugoårsminnet av hans död, 1973, hölls en vetenskaplig konferens i Genève med utgångspunkt $\mathrm{i}$ hans texter. Då bildades också Association for the Study of the Work of Henri de Man. Till hundraårsminnet av hans födelse 1985 ordnade hans hemstad Antwerpen en utställning om honom. Även Marcel Déat fick viss upprättelse då hans memoarer publicerades postumt 1989. ${ }^{569}$ Det kan te sig märkligt att de Man och Déat, som rent sakligt båda var involverade i kollaboration under kriget, mötts av mer förståelse för sitt agerande än de båda svenskarna. De var ju aldrig i närheten av något liknande. Möjligen är det just ockupationshistorien som gör avstegen lättare att bortse från - ställda inför ett yttre tryck fanns inga andra val än kollaboration.

\section{Renegater i politiskt lärande - några tankar}

Allra sist ska något sägas om vad som kännetecknar de olika renegaternas övergångar i termer av lärande. Finns det något särskilt som betingar dessa processer? Hur sker omprövningen, kan stegen identifieras? Vad är det man anser att man lärt sig i sin övergång, och vem är det egentligen som lär? Den i litteraturen om de nämnda renegaterna som kommer närmast de här frågorna är White, då han identifierar ett antal steg $\mathrm{i}$ övergången, ofta med en kritik av den ortodoxa marxismens förutsägelser och postulat som grund. Det var alltså det man i ett första läge trott på som i en ny situation inte längre gällde. Förutsägelserna fungerade inte och behövde omprövas för att det politiska budskapet skulle hänga ihop bättre. Lavelle närmar sig, förmodligen omedvetet, en liknande tanke. Det gör han dels då han talar om upplevelsen av förlust som ett viktigt rekvisit för omprövning, dels genom att tala om "fläckar" i den radikala förkunnelsen som tidigt skulle visa att den enskilde aktören var på väg i konservativ riktning. I båda dessa fall pekar Lavelle på faktorer, yttre 
eller i idémängdens kärna, som skapar eller visar på bristande idémässig koherens. Omprövningen innebär i detta avseende ett sökande efter en uppsättning idéer som hänger bättre ihop än de idéer man överger.

\section{Negativa begrepp}

Den som går längst i att extrahera generella ideologiska mönster i renegatlitteraturen är Sørensen. Han gör det i relation till norska Nasjonal Samling och dess idéer för att spåra vad som här kan kallas socialism, men också för att kunna se vilka idémässiga kontinuiteter som finns att se över tid hos renegaterna med hemvist i detta parti. Han identifierar bland annat tron på revolutionen, arbetarnas historiska rätt och den starka staten som viktiga, positivt uttryckta ideologiska delmängder, som uttryckte vad man ville uppnå. Men en särskilt viktig roll spelar också de negativt uttryckta ideologiska begreppen, det man polemiserar mot och aktivt vill bekämpa. Det har redan i rekapituleringen av Whites tankar konstaterats att antikapitalismen är helt central för de europeiska renegaterna, och det gäller som vi sett också i de båda svenska fallen. Utöver motståndet mot kapitalismen talar Sørensen bland annat om ett motstånd mot liberalism, mot politisk demokrati och parlamentarism, och mot socialdemokratin. Mellan dessa negationer råder en betydande överlappning. ${ }^{570}$

Också i fallen Flyg och Lindholm är de negativt uttryckta begreppen avgörande.$^{571}$ I flera fall är det just dessa som överbryggar aktörernas båda faser. Detta är med andra ord ett helt centralt forskningsresultat: ofta hävdas att en ideologi inte kan definieras genom sina uttryckta antipatier. Det skäl som anges är att ett negativt uttryckt begrepp, exempelvis "antikapitalism", är mångtydigt och har många vitt skilda konklusioner. Även Michael Freeden är inne på denna tanke då han menar att en ideologi inte kan definieras huvudsakligen genom vad som negeras. Resultaten här visar dock att det tvärtom är de negativt uttryckta begreppen som är mest centrala då det gäller renegater. Skälen är två: för det första för att negationerna är just mångtydiga, vilket i en övergångsprocess är en fördel. För det andra för att de tydligt markerar i vilken riktning en ideologisk övergång absolut inte kan gå. 
Dessa förhållanden gör det i sin tur intressant att pröva ett par tankar. För det första att det kan vara möjligt att spåra en genom åren överordnad ideologisk antipati som dröjer sig kvar som särskilt essentiell, och som förklarar varför ställningstaganden i viss riktning inte leder till konklusioner som annars vore inom räckhåll. Då det gäller Flyg kan det exempelvis noteras att han vid 30 -talets slut vid flera tillfällen jämställer Stalins Sovjet och Hitlers Tyskland som jämbördiga diktaturer. På denna punkt säger han inget som inte kunde ha sagts av en genomsnittlig folkpartist vid samma tid. Men det är inte till Folkpartiet han går. Antikapitalismen är alltför viktig för detta. Av detta skäl blir Flyg heller aldrig socialdemokrat, trots att det var många partikamrater som över åren gick i den riktningen. För Flyg var dessa de riktiga renegaterna. Han övervägde till och med polisanmälan mot dem som spekulerade i att det var mot socialdemokratin han var på väg. ${ }^{572}$

För det andra väcks tanken att potentiella renegater kan spåras genom att de definierar sig ensidigt negativt. Även om det jämte de negativt uttryckta begreppen hos Flyg och Lindholm finns en tro på de positiva kontrasterna - arbetarstaterna - så kan det konstateras att vagheten på denna punkt är betydande. Om kapitalismen vet man vad man tycker, man vet varför - den stjäl arbetarens möda, alstrar kriser etcetera - och man vet också vad den för med sig i termer av imperialism och militarism. Alltså ska den förskjutas, och socialismen ska byggas istället. Men hur ska denna socialism se ut, bortsett från att den ska negera de karaktärsdrag som kapitalismen anses ha? Här är otydligheten mera påfallande. Potentiellt finns här en nyckel till övergången: negationen är konstant och tydlig, men negationens konsekvens - socialismen mera vag och förhandlingsbar. För det tredje är det, slutligen, intressant att notera att de ideologiska företrädarna för två politiska projekt som oftast brukar betraktas som i grunden utopiska, inriktade mot det goda samhälle man i framtiden avser att bygga, i så hög grad definierar sig mot vad man absolut vill undvika och att denna ömsesidiga negativitet förebådar en symmetrisk ideologisk övergång. 


\section{Omprövning och koherens}

Definierande för renegaternas förflyttning är alltså en stark kontinuitet i de uttryckta antipatierna. Icke desto mindre finns också ett positivt idéinnehåll, uttryckt inte minst i tron på arbetarstaten: det socialistiska föredömet som går i bräschen i kampen mot kapitalismen. Att flera av renegaterna har ett så dialektiskt präglat tänkande förstärker bilden. En socialist är antikapitalist och en kapitalist är antisocialist. Begreppen förutsätter varandra och de historiska realiteterna uttrycks ofta på detta sätt. Samtidigt förändras synen på vem som är det socialistiska föredömet uppenbarligen i en stegvis omprövning, en process som kan analyseras närmare.

Som inledningsvis noterades för Freeden sitt metodologiska resonemang delvis med inspiration av Reinhart Koselleck och dennes begrepp "erfarenhetsrum". För Freeden ger detta begrepp en möjlighet att illustrera både interdependens och koherens. På samma sätt som begreppen på det semantiska fältet avgör varandras betydelse i ett internt sammanhang, länkar också erfarenheter i varandra och formar för den enskilde en sammanhängande erfarenhetskunskap som möjliggör välgrundade beslut och rationellt handlande. I erfarenhetsrummet samlas det vi lärt oss. Erfarenhetsrummet är för Freeden också en möjlighet att peka ut vissa begrepp - kärnbegreppen - som mer essentiella än andra, återigen genom den rumsliga analogin. Ett kök behöver en spis och en diskbänk liksom liberalismen behöver begreppet frihet. Annat är inte lika oförytterligt. I förståelsen av erfarenhetskunskapen som rumsligt organiserad, och behovet av att erfarenheterna i detta rum ska vara åtminstone hjälpligt sammanhängande för att vi ska kunna använda dem i vårt agerande mot framtidshorisonten, visar Koselleck och Freeden på saker som är viktiga också i denna undersökning.

Men det finns också skäl att dröja vid själva begreppet "erfarenhet", hur denna skapas och förändras. Helt centralt för Koselleck är som sagt tanken att vår erfarenhet intimt samspelar med vår förväntan. Erfarenheter skapar förväntan, och det är utifrån denna erfarenhetsgrundade förväntan vi väljer att handla på olika sätt. Men erfarenheten är också genom detta utsatt för ständig prövning: om det vi förväntar oss inte inträffar omprövar vi våra erfarenheter. Vi anser oss veta bättre, 
och genom att ompröva vad vi upplevt har vi också reviderat vår erfarenhetskunskap. Att ompröva en enskild erfarenhet innebär också, på samma sätt som för begreppen på Freedens semantiska fält, att övriga erfarenheter i den totala erfarenhetsmängden hamnar i ett annat ljus. Om denna process fortgår över tid, och alltfler delar av det som i utgångsläget var den samlade erfarenhetskunskapen revideras, uppstår det småningom problem med koherensen. Detta får i sin tur betydelse för erfarenhetskunskapens kapacitet att ge oss råd för vårt handlande. Då mister den sin funktion, och vi tvingas att omvärdera antingen de kvarvarande erfarenheterna eller de som nyligen vunnits. Denna totala omprövning kan för den enskilde vara existentiellt utmanande, och det finns därför ett visst motstånd mot den. Detta motstånd kan hanteras på olika sätt. Antingen kan man negligera den bristande koherensen, eller så kan man välja att se vad som för många andra framstår som en högst central erfarenhet som ett falsarium. Ofta verkar ändå trycket, det erfarenhetsmässiga och det sociala, i längden för en omprövning.

Denna erfarenhetsdynamik är också verksam i en ideologisk omprövningsprocess. Såväl Lavelle som White tangerar tankegången; Lavelle genom att tala om upplevelsen av nederlag som en betingande faktor bakom ett ideologiskt avfall, White genom att lyfta första världskriget och den tidiga mellankrigstidens händelser som en serie generationsspecifika erfarenheter. I linje med Lavelle, White och den historieteoretiska ram som Koselleck erbjuder ska nu ett par noteringar kring de ideologiska lärprocesserna göras.

För det första kan man se att omprövningen sker i steg. Detta konstaterar också White, exempelvis då han följer hur renegaternas ifrågasättande av marxismens fatalism leder till idéer om statlig ekonomisk planering som ett första steg bort från den ortodoxa marxismen. Liknande resonemang går också att applicera på svenskarna. I Lindholms fall har det exempelvis konstaterats att hans omvärdering av Hitler och dennes politik har tre principiella steg. I ett första läge förnekas allt. Det som framkommer om förintelseläger och krigsbrott betraktas som lögner. Det är en god illustration till vad som sagts ovan om förnekelse som ett sätt att undvika erfarenhetsmässig omprövning. I ett andra läge är detta hårda förnekande något uppmjukat. Brotten 
anses nu ha förekommit, men skulden fördelas på ett sådant sätt att Hitler och nationalsocialismen går oanfrätt ur omprövningen. Istället lanserar Lindholm en funktionalistisk förklaringsmodell, och skjuter ansvaret för förbrytelserna till Tredje rikets statliga byråkrati med följden att ett personligt ansvar inte kan utkrävas. I ett tredje läge har dock det erfarenhetsmässiga trycket blivit för stort. Det är då inte bara tidningspressen, som tidigare regelmässigt ansetts ljuga, som hävdar att ett folkmord begåtts utan även Lindholms tyska vänner. I detta läge sluter Lindholm upp bakom en tolkning som betonar de ideologiska intentionerna bakom det nazistiska förtrycket. Följden blir att nationalsocialismen inte längre utgör ett politiskt alternativ - den idealistiska socialism som Lindholm letat efter får han nu söka någon annanstans. Att han i detta tredje läge uppfattar Hitlers politik som en "urspårning" av nationalsocialismen som han förstått den ligger i korten.

Just det faktum att Lindholm i sin omprövningsprocess lanserar en funktionalistisk förklaring till de tyska krigsbrotten som ett slags mellansteg har också viss motsvarighet i fallet Flyg. För Flyg blev motståndet mot Komintern med tiden helt avgörande, men i sin första version vid splittringen 1929 var motståndet ganska milt. Det var egentligen inte Komintern det var fel på, snarare ett antal personer i organisationens topp som inte förstod socialismens grundvalar. Liksom hos Lindholm kan man här se en tendens att vilja lägga felet där det får minst politisk-ideologisk konsekvens för en själv eftersom en sådan omprövning är krävande. Det är inte Komintern eller Hitler det är fel på, det är någon annan. Antingen enskilda personer i Komintern eller statsapparaten i Tyskland.

För det andra kan man i fallen Flyg och Lindholm se tydliga indikationer på att de i sina respektive övergångar ökar koherensen i den egna idémängden. Flera exempel kan ges. Flygs splittrade bild av Komintern och Sovjet leder över tid till ett stringent ställningstagande mot allt som kan knytas till den samtida ryska kommunismen. Att värdera ryska kommunister i Kominterns topp och den ryska kommunismen på diametralt olika sätt blev i längden logiskt ohållbart. En motsvarande paradox är Flygs betoning av nationella särdrag inom ramarna för en programmatiskt internationalistisk kommunism under det tidiga 30-talet. Också denna paradox försvinner i takt med att Flyg förflyttar sig alltmer tydligt till 
det nationella politiska lägret. Allmänt verkar just paradoxerna i de båda aktörernas ställningstaganden med åren bli färre. Exempelvis försvinner i Lindholms fall den logiska motsättningen mellan å ena sidan ett fokus på fördelning av en produktionsvinst och å andra sidan en polemik mot produktion som sådan. Även i detta fall ökar alltså koherensen i ställningstagandet. Man kan fråga sig om detta är en indikation på att de båda aktörerna ser sprickor i sin egen världsbild, och söker efter en mer helgjuten ideologisk position. I så fall är detta kompatibelt med Kosellecks och Freedens tankar om att erfarenhetsmängden såväl som det politiska språk som uttrycker denna måste hänga ihop.

En tredje och avslutande aspekt relaterad till frågan om renegater och lärprocesser är vem det är som egentligen lär. Som sagts upplever renegaterna, inte minst Flyg och Lindholm, en urspårning och ett svek mot deras respektive politiska projekt. Det är detta svek som i hög grad dikterar deras övergång. I själva verket innebär detta att det ur renegatens synvinkel inte är han som är renegat - renegat bör rätteligen den kallas som sviker den sanna radikalismens idé. Detta ger i sin tur kontur åt de ideologiska kontinuiteterna, något som både Flyg och Lindholm själva lyfter fram: man tycker inte själv att man förändrats, i alla fall inte så mycket.

Man kan också fråga sig hur personer i "den nya ideologiska hemvisten" upplever Flygs respektive Lindholms övergång. Det finns indikationer på att den tas emot utan motvilja. I någon mån blir Flyg och Lindholm skalper för den egna saken, det ultimata belägget för att man haft rätt och dessutom förmått värva en tidigare fiende. Lindholm skriver i denna linje vackert om Doriot. Gunnar Prawitz, Fredrik Schéle och Per Engdahl nedtecknar alla vackra ord om Flyg då han närmar sig den nationella idémiljön. Det gäller inte bara i de erkännsamma dödsrunorna från 1943.

Också beträffande Lindholm kan konstateras att han i den senare intervjun i kommunistiska Ny Dag bemöts med respekt. Perspektivet är explicit att Lindholm "lärt om", något som också bildar grunden för att han bemöts med sympati. Detta är dock som sagt inte med nödvändighet Lindholms eget perspektiv. En avslutande fråga är därför om det är rimligt att tala om ett lärande när kontinuiteterna är så starka, och där den enskilde själv upplever en stark kontinuitet? För vem är renegaten en renegat, och vem är det egentligen som har lärt något? 